\title{
Landslide Analysis Using Seismic Refraction Tomography and MASW: a Case Study in Ponorogo, East Java, Indonesia
}

\author{
Yusri Prayitna ${ }^{1}$, Widya Utama ${ }^{1}$, Dwa Desa Warnan ${ }^{1}$
}

\begin{abstract}
Ponorogo district morphology form consisting of highlands and hills make this area vulnerable to landslides. Based on the BNPB (National Disaster Management Agency) data from 2013 to 2017, 77 landslides and 35\% have occurred in Ngrayun and Slahung sub-districts. One area that has the potential to experience landslides is Tugurejo village in Slahung District. This study aims to determine the physical properties of subsurface rocks using SRT (Seismic Refraction Tomography) and MASW (Multi-channel Analysis of Surface Waves). The seismic velocity distribution defined from the SRT and MASW at the study sites shows a zone with a higher porosity that is interpreted to represent the level and depth of rock mass movement. P-wave velocity and S-wave indicates very low velocity of $500-1200 \mathrm{~m} / \mathrm{s}$ and $100-250 \mathrm{~m} / \mathrm{s}$ at depths up to $5 \mathrm{~m}$.
\end{abstract}

Keywords — Seismic Refraction Tomography, Multi-channel Analysis of Surface Waves, Landslide

\section{INTRODUCTION}

$\mathrm{P}$ onorogo is one of the areas in Indonesia that has a real landslide threat, this is due to the varied morphology of Ponorogo Regency such as the highlands and hills [1]. Based on data from the BNPB (National Disaster Management Agency), from 2013 to 2017 there have been 77 landslide events and 35\% of them occurred in Ngrayun and Slahung sub-districts. One of the potential landslide areas is Tugurejo village in Slahung District. In this area, there have been movements of the ground and cracks appear in some places that cause considerable losses. Based on information from residents, the movement of soil and cracks occurred after heavy rain for several days. The landslide study of this area is critical because the area undergoing land movement and cracks is on a national road connecting Ponorogo Regency with Pacitan Regency.

In recent years, landslide research has been done using geophysical techniques to characterize landslides. One of the frequently used methods is refraction seismic [2], [3]. Landslide analysis is carried out based on the physical properties of rock in the landslide with the surrounding rock which is more stable. This difference is influenced by several factors such as deformation, fractures, water content, and porosity [3]. According to [2] in the context of landslide characterization, tomographic refractive seismic is most often applied because the P-wave seismic velocity usually shows significant differences between landslides and underlying bedrock. While the results of [3] also showed a very low $\mathrm{S}$-wave velocity value in the landslide area compared to the more stable area around it.

\footnotetext{
${ }^{1}$ Yusri Prayitna, Widya Utama, Dwa Desa Warnan are with Department of Geophysics Engineering, Insitut Teknologi Sepuluh Nopember, Keputih, Sukolilo, Surabaya 60111, Indonesia. E-mail: yusri.prayitna@gmail.com; dwa_desa@geofisika.its.ac.id.
}

This research includes the analysis of geophysical measurements by using refraction seismic method and MASW to determine the vertical and lateral limits of a landslide in Tugurejo.

\section{STUDY AREA}

Based on the calculation of the height difference and slope on the topographic map in the study area, Tugurejo is included in the category of strong corrugated geomorphology units. This geomorphological unit is composed of lithology in the form of lapilli and andesite lava. The primary factor that controls the geomorphology unit in this area is an intensive denudational or undergoes weathering and erosional processes which results in the bedrock being exposed well.

Based on regional geological map of Pacitan, the stratigraphic research consists of various sediments. The northern Slahung is dominated by young Quarter aged sediment consisted of alluvium deposits. Meanwhile, the southern part is dominated by old sedimentary rocks from Oligocene to Miocene age. The research area belongs to the Watupatok formation. This unit is composed by andesite lava, coarse tuff, and andesite breccia. The composition of andesite lava is a group of intermediate minerals [4].

Analysis of the SRTM (Shuttle Radar Topography Mission) shown there are several straightness patterns in the Slahung area but generally can be grouped into two main directions namely the Northwest-Southeast and Northeast-Southwest. From the results of the lineament analysis, the potential landslide area of Tugurejo is between ridge and valley oriented to the Northwest-Southeast direction which is lineament pattern of strike-slip in the north of the study area (Figure. 2). The results of [5] showed a correlation between lineament and landslide vulnerable areas where areas with lineament density are 
more susceptible to landslides. The study area has a slope facing the Southeast.
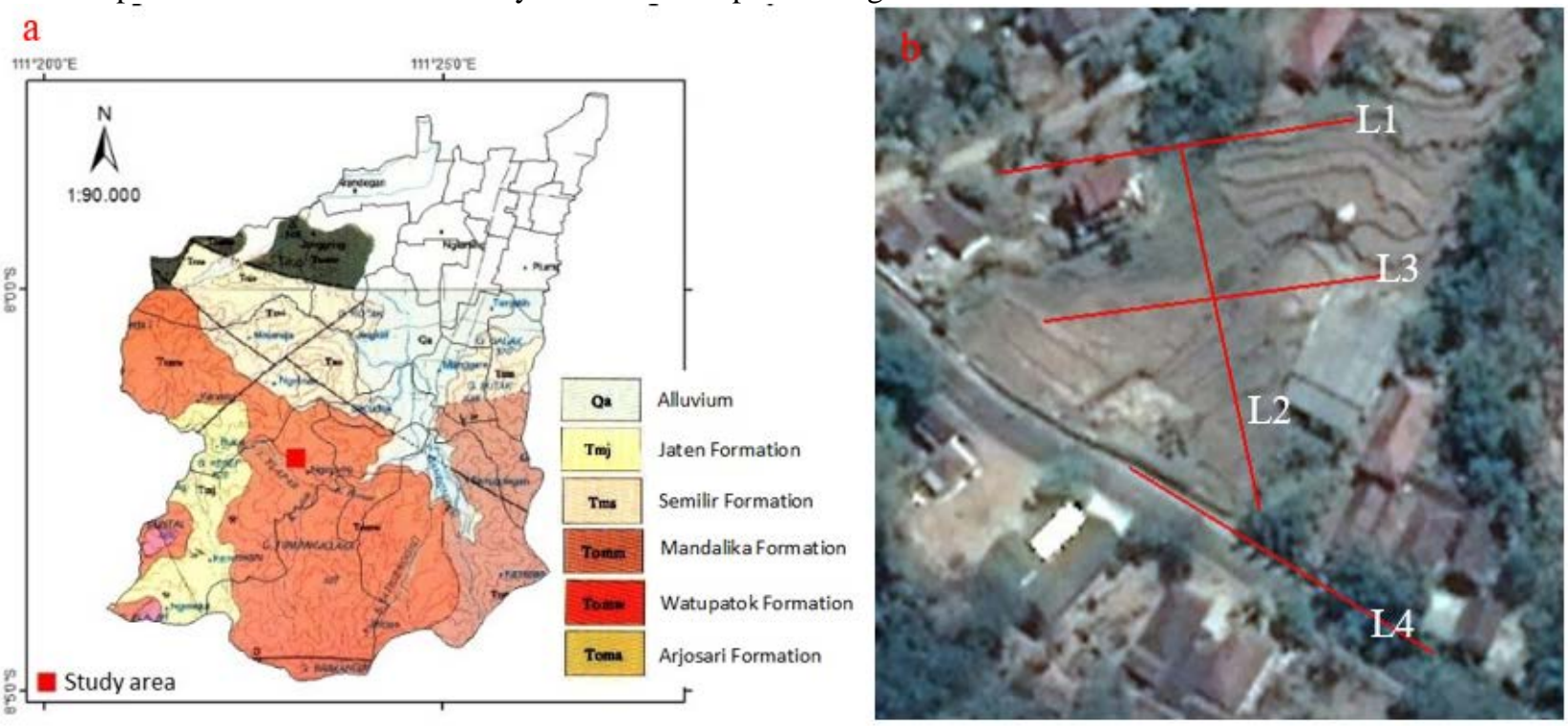

Figure 1. a) Regional geological map of Slahung area; b) Measurement path.

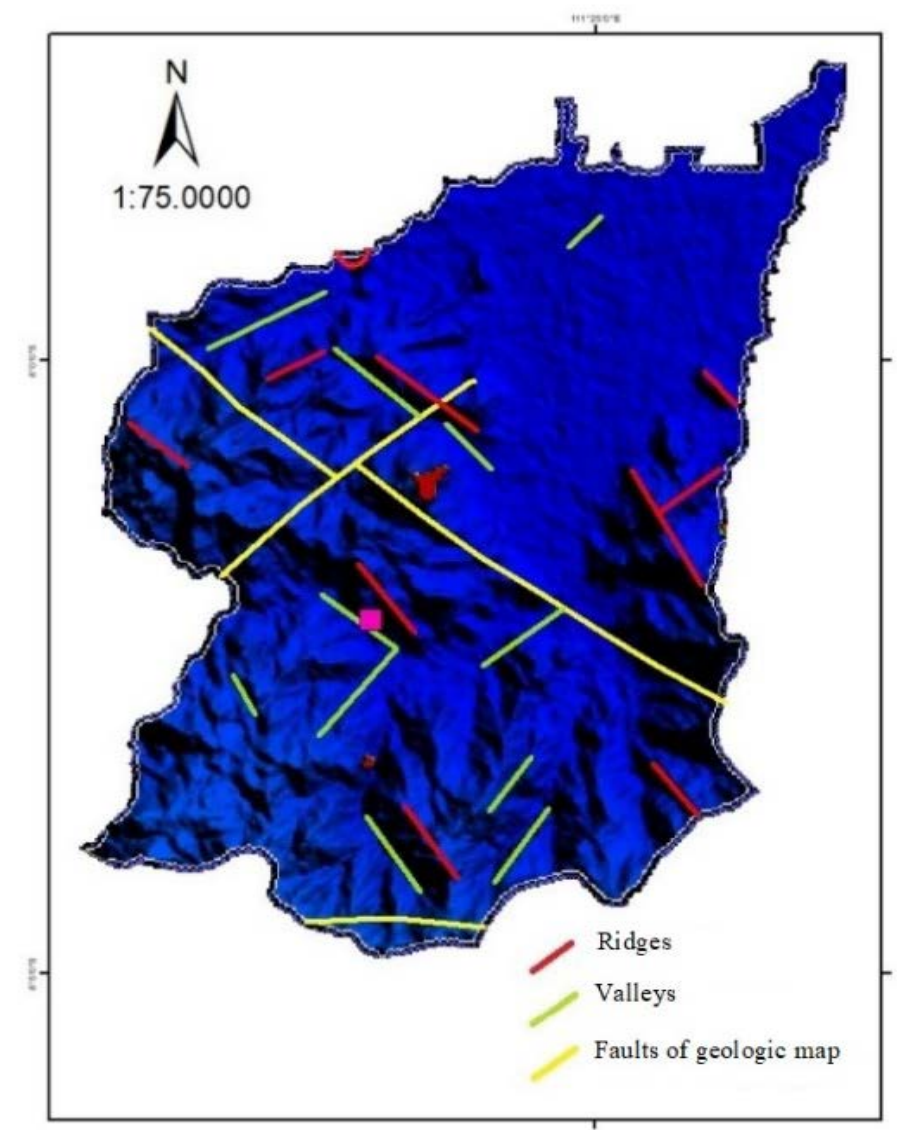

Figure 2. Slahung lineament map (pink is the location of measurement).

\section{METHOD}

The seismic data acquisition consists of P-wave refraction and MASW performed on four profiles. The length of the measuring path is $69 \mathrm{~m}$, with the number of geophones as much as 24 with the distance between geophone $3 \mathrm{~m}$.
One measurement profile is made parallel to the landslide field in the Northwest-Southeast direction, and the other profiles are formed perpendicular to the landslide field (Figure 1b). In data acquisition for each seismic profiles used a $5 \mathrm{~kg}$ hammer as a seismic source.

Five shots were performed on each measurement profile: two shots were placed at the end of the profile with a 5-m 
offset, the other three firing performed between geophones 6 and 7, 18 and 19, and in the middle of each profile. In the case of path 2, due to the constraints in the measurement so that the first shoot point that should be at one end of the profile must be moved to the position between geophone 2 and 3 . The acquisition parameters used are $2 \mathrm{~s}$ time record and $1 \mathrm{~ms}$ sampling rate.

Seismic data were analyzed using ZondST2D software for P-wave Tomography and easy MASW for VS 1D modeling. Figure 3 also shows analysis steps for refraction and MASW data.

\section{RESUlts AND DisCUSSION}

Based on seismic-refraction analysis results, the 2D crosssection (Figure 4a) can explain the subsurface structure of the research area. The P-wave velocity model in Figure 4a shows a subsurface profile consisting of four layers, ranging from $500 \mathrm{~m} / \mathrm{s}$ to $2,800 \mathrm{~m} / \mathrm{s}$. The result of seismicrefraction analysis reaches $25 \mathrm{~m}$ depth.
The top layer with a P-wave velocity between 500 - 1200 $\mathrm{m} / \mathrm{s}$, represented by blue, is a breccia layer with a sandstone tuff matrix as encountered in the measurement location. This layer reached up to $8 \mathrm{~m}$ deep in the Northwest and thinned up to $4 \mathrm{~m}$ in the Southeast. This layer is interpreted as a mass movement zone. Below this layer is a layer of saturated clay with a P-wave velocity of $1200-1600 \mathrm{~m} / \mathrm{s}$ with a thickness of $5 \mathrm{~m}$. The next layer with velocity range between $1600-2200 \mathrm{~m} / \mathrm{s}$ is a more compact clay layer. This layer has a thickness of $5 \mathrm{~m}$. The last layer is a sandstone bedrock with P-wave Velocity $2200-2800 \mathrm{~m} / \mathrm{s}$. The values of P-wave velocity analysis results similar to the velocity values identified in the literature for similar land material [6]. Figure $4 \mathrm{~b}$ is a landslide geometry, the red line representing the vertical boundary and the black line representing the lateral border of the landslide. Massmovement is a sandstone tuff that lies above a layer of saturated clay that acts as a field of slip.

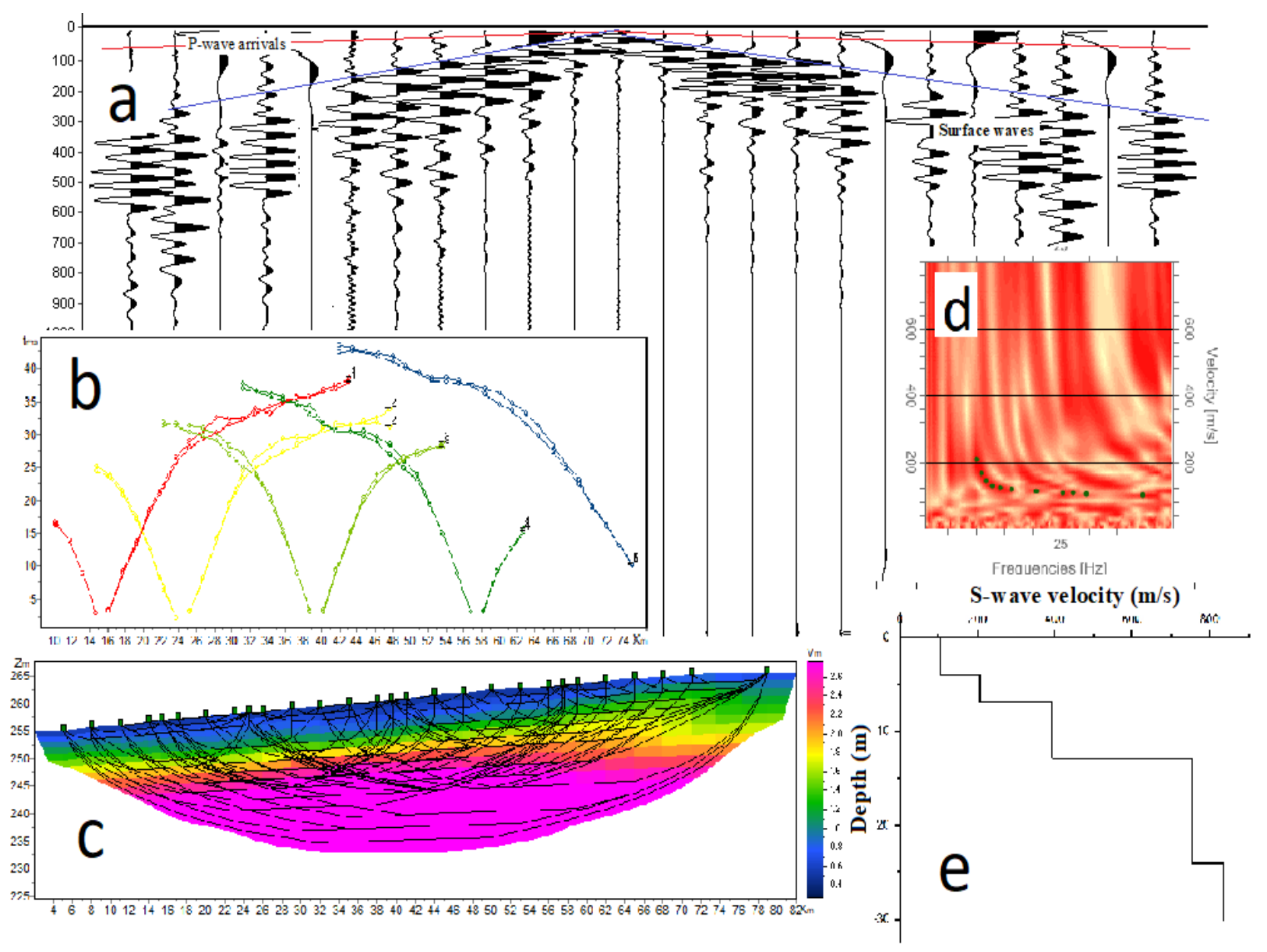

Figure 3. Raw seismic data and refractive seismic analysis steps and MASW. 


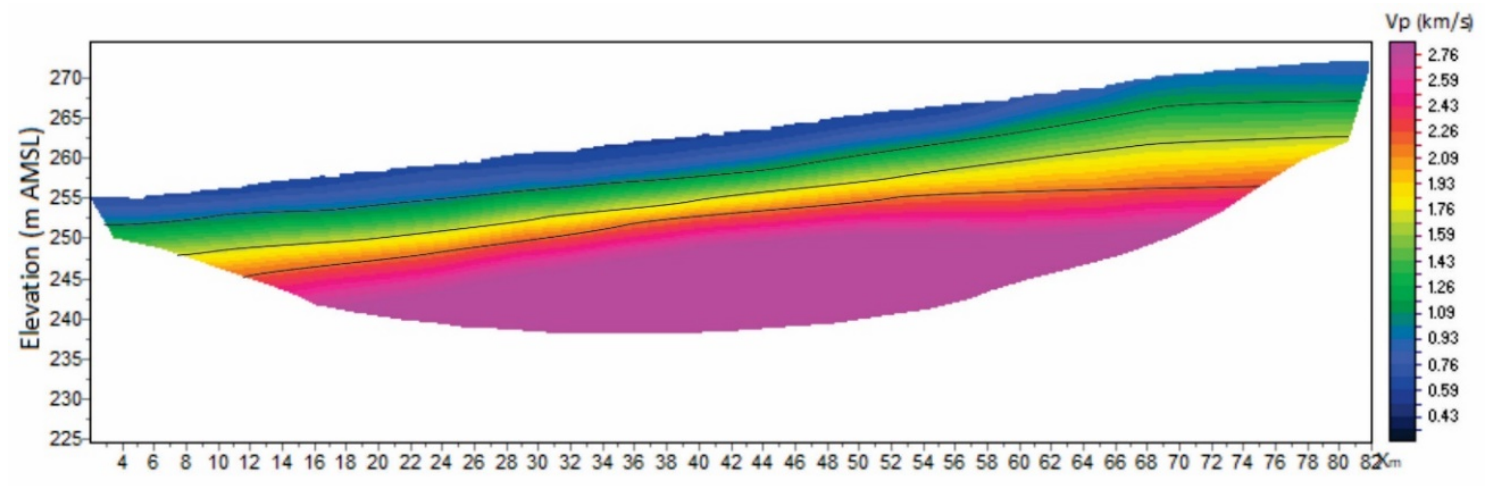

(a)

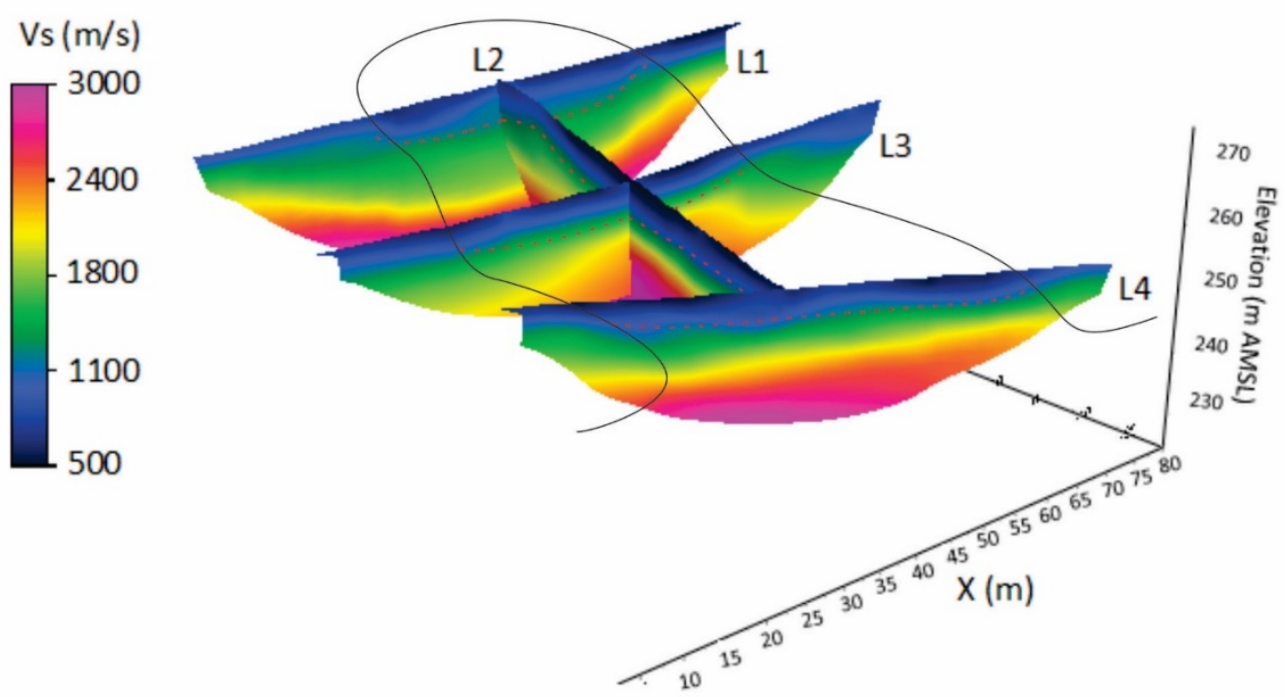

Figure 4. a) The profile of P-wave 2D on track 2; b) P-wave 3D velocity profile for all measurement paths.

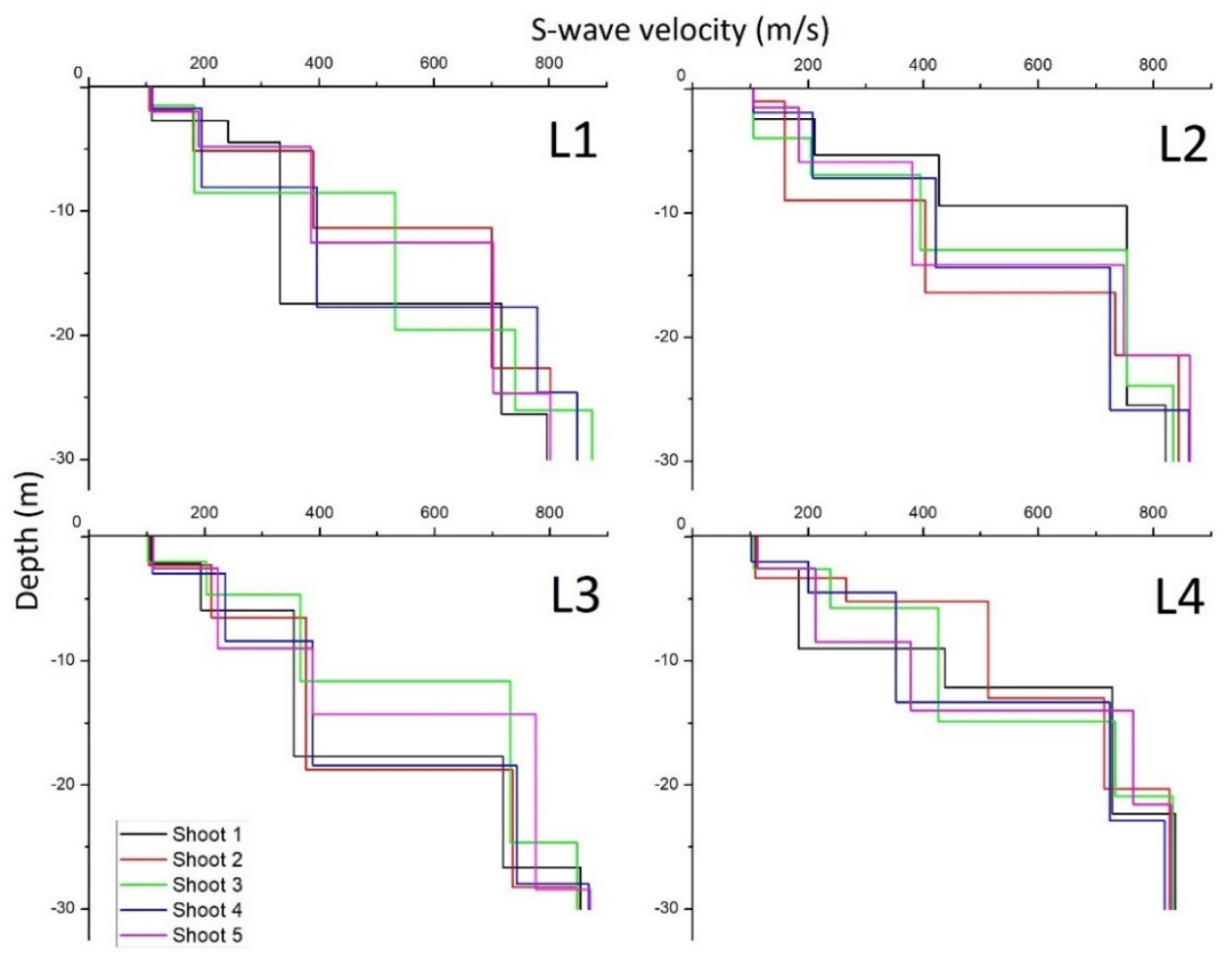

Figure 5. S-wave velocity on each measurement path. 


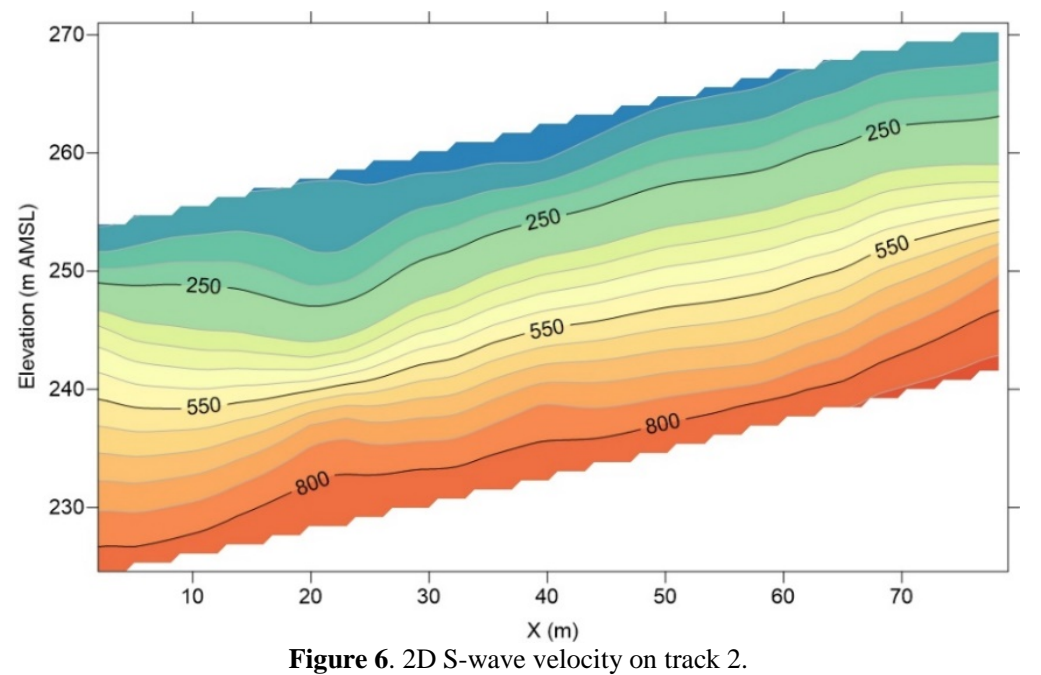

Figure 6 shows the S-wave velocity profile. The 2D Swave velocity profile in Fig. 6 is obtained from the 1D cross-sectional interpolation which is the result of MASW analysis of each shoot-point. As shown in Figure 5, the penetration depth for MASW measurements is a maximum of $30 \mathrm{~m} \mathrm{[7].} \mathrm{In} \mathrm{the} \mathrm{dispersion} \mathrm{curve} \mathrm{modeling,} \mathrm{a} \mathrm{synthetic}$ model is used which refers to the geological information and outcrops obtained in the research area consisting of three layers. So the synthetic model is made five layers, assuming each layer has two different wave velocity values because of the depth factor.

The result of the S-wave velocity profile shows a significant increase in wave velocity as the depth increases for each profile. Low $\mathrm{S}$-wave velocity range from $100-$ $250 \mathrm{~m} / \mathrm{s}$ at the top layer and increase to $850 \mathrm{~m} / \mathrm{s}$ at a depth of $30 \mathrm{~m}$. Figure 5 shows the existence of three layers that have very different contrast velocity values. This difference in velocity value is indicated concerning the geometry of landslides.

The vertical cross-section of the S-wave velocity shown in Figure 6 is more accessible to interpret to the landslide geometry. Trajectory 2 which is parallel to the landslide field shows an S-wave velocity value lower than $250 \mathrm{~m} / \mathrm{s}$ at a depth of $8 \mathrm{~m}$ in the Northwest and depletes up to $4 \mathrm{~m}$ towards the Southeast corresponding to the landslide geometry interpreted on the $\mathrm{P}$-wave velocity analysis (Figure 4a). The S-wave velocity value for all profiles is stabilized at a depth of 25 to $30 \mathrm{~m}$ with an average velocity of $830 \mathrm{~m} / \mathrm{s}$. These results indicate that this layer is more stable and compact.

\section{CONCLUSION}

The purpose of this study was to analyze and determine the vertical and lateral boundaries of landslides in Tugurejo.
P-wave and S-wave velocity profile produce sub-surface geological models making it easy to characterize landslide problems. The results of the analysis show that there are low Vp and Vs values of $500-1200 \mathrm{~m} / \mathrm{s}$ and $100-250 \mathrm{~m} / \mathrm{s}$ respectively. This layer is a layer of sandstone tuff interpreted as a mass movement with a thickness of 4 to 8 $\mathrm{m}$ that increasingly thickened from the southeast to the northwest. This layer rises above the saturated clay which can act as a slip field. This saturated clay layer has a thickness of up to $8 \mathrm{~m}$.

\section{REFERENCES}

[1] H. Yuniarta, "Kerawanan bencana tanah longsor Kabupaten Ponorogo,” Universitas Sebelas Maret, 2014.

[2] S. Uhlemann et al., "Landslide characterization using P- and Swave seismic refraction tomography - The importance of elastic moduli,” J. Appl. Geophys., vol. 134, pp. 64-76, Nov. 2016.

[3] E. Yalcinkaya et al., "Near-surface geophysical methods for investigating the Buyukcekmece landslide in Istanbul, Turkey,” J. Appl. Geophys., vol. 134, pp. 23-35, Nov. 2016.

[4] H. Samodra, Pusat Penelitian dan Pengembangan Geologi, S. Gafoer, and S. Tjokrosapoetro, Lokasi: Peta geologi lembar Pacitan, Jawa. Bandung: Pusat Penelitian dan Pengembangan Geologi, 1992.

[5] N. Yusof, M. F. Ramli, S. Pirasteh, and H. Z. M. Shafri, "Landslides and lineament mapping along the Simpang Pulai to Kg Raja highway, Malaysia,” Int. J. Remote Sens., vol. 32, no. 14, pp. 4089-4105, Jul. 2011.

[6] C. Lissak et al., "Airborne and ground-based data sources for characterizing the morpho-structure of a coastal landslide," Geomorphology, vol. 217, pp. 140-151, Jul. 2014.

[7] C. B. Park, R. D. Miller, J. Xia, and J. Ivanov, "Multichannel analysis of surface waves (MASW) - active and passive methods," Lead. Edge, vol. 26, no. 1, pp. 60-64, Jan. 2007. 